\title{
POSLOVICE U VITEZOVIĆEVU ODILJENJU SIGETSKOM
}

Izvorni znanstveni članak Primljeno: 2. 7. 2019 Prihvaćeno: 2. 9. 2019

DOI: $10.15176 /$ vol56no207

UDK 821.163.42.09Vitezović, P.R. $821.163 .42-84$ 27-243.65

\section{VANJA BUDIŠĆAK}

Zavod za povijest hrvatske književnosti, kazališta i glazbe HAZU, Zagreb

\begin{abstract}
Među brojnim književnim žanrovima što ih je Pavao Ritter Vitezović (1652. - 1713.) uključio u svoj vrstovno hibridan "spjev" Odiljenje sigetsko (1684) posebno mjesto pripada poslovicama. Raspršene u sva četiri dijela teksta, poslovice su jedan od najzastupljenijih žanrova u Odiljenju, ali i u Vitezovićevu bogatom i raznorodnom stvaralačkom opusu uopće. U radu se stoga upozorava na značenjsku (semantičku) raznolikost poslovica u Odiljenju sigetskom, istražuje njihovo moguće porijeklo (usmena/pisana književnost) i funkcija unutar samoga "spjeva", a uspoređuje ih se i s poslovicama iz nekih drugih Vitezovićevih djela na hrvatskom jeziku. Analiza će pokazati da je sveprisutnost poslovica u Odiljenju zapravo odjek izrazite barokne sklonosti (usmenoknjiževnim) poslovicama i paremiologizmima, ali i jasan dokaz Vitezovićeve želje da svoje djelo približi (i) slabije obrazovanim čitateljima.
\end{abstract}

Ključne riječi: Pavao Ritter Vitezović, Odiljenje sigetsko, poslovice, usmena književnost

Neovisno od činjenice da su već tada bile prepoznate kao "dva posve različita vida jezičnog stvaralaštva" (Solar 1996: 128), pisana i usmena ("narodna") književnost osobito su se intenzivno u nas preplitale u 16. i 17. stoljeću, kada mnogi autori - od Marina Držića i Petra Zoranića, preko Petra Hektorovića i Jurja Barakovića, sve do Ivana Gundulića, Ignjata Đurđevića i braće Zrinski - svoja djela ciljano obogaćuju raznim autohtono usmenoknjiževnim elementima, pa čak i nekim manjim folklornim žanrovima u cijelosti. 'Zahvaljujući potonjoj praksi, danas se sa sigurnošću može tvrditi da su naši renesansni i barokni pisci posebno bili zaintrigirani žanrom poslovice, koju je - u izvornom obliku ili stiliziranu - tek rijetko koji od njih propustio uvrstiti u neko od svojih ostvarenja. Pritom se, naravno, ne smije zaboraviti da je prije spomenutog razdoblja poslovica već stoljećima paralelno egzistirala i kao žanr pisane književnosti, a osim što su onodobni autori te činjenice bili i više nego

' Detaljno o prožimanju usmene i pisane književnosti u razdoblju naše renesanse i baroka u BoškovićStulli 1978: 152-217. 
svjesni, i sami su poslovičnu "građu" za svoja djela nerijetko crpili i s toga njima bliskijeg izvora.

\section{ZADIVLJEN(I) POSLOVICAMA}

Usprkos njezinoj višetisućljetnoj ukorijenjenosti u oba vida jezičnoga stvaralaštva, znanstveni interes za žanr poslovice dosad su u nas iskazivali većinom stručnjaci za folklornu književnost. Rezultiralo je to, dakako, sveopćim prihvaćanjem poslovice kao isključivo usmenoknjiževnoga kratkog, odnosno "jednostavnog" ili - u novije vrijeme - "minimalističkog"“3 oblika, koji u vrlo sažetoj formi (najčešće svedenoj na tek jednu rečenicu) donosi univerzalno primjenjivo poučno zapažanje o stanovitoj životnoj pojavi proizišlo iz pojedinčeva životnog iskustva i usklađeno sa svjetonazorom čitave zajednice. Ta se definicija, međutim, bez imalo oklijevanja može protegnuti i na pisanoknjiževne poslovice, također presudno obilježene istinitošću, kratkoćom i iskustvenim polazištem, a pridoda li se tim temeljnim značajkama žanra poslovice još i izrazit "poantni karakter" (Čubelić 1988: 317), postat će posve razumljivo zašto su - bez obzira na svoje porijeklo - u gotovo svim književnim epohama poslovice često uključivane u veće (pisane) forme. Štoviše, zahvaljujući izuzetnoj postojanosti njezine strukture i spomenutoj univerzalnosti značenja, poslovica se u povijesti svjetske književnosti i izdvaja kao jedan od tek nekoliko žanrova dugoga trajanja, a činjenica da je - bitno promijenjenim društvenopovijesnim i književnim okolnostima usprkos - potreba za poslovičnim koncentracijama životnog iskustva jaka još i danas objašnjava zašto je i poslovicu "staru" nekoliko stoljeća većina suvremenih čitatelja u stanju žanrovski prepoznati "na prvi pogled".

Sastavljajući svoje preglede žanrova usmene književnosti, (domaći) folkloristi u "pretinac" jednostavnih (kraćih) oblika ili "mikrostruktura" (Dragić 2006: 524) zajedno s poslovicom obično svrstavaju još i usmenu zagonetku. ${ }^{4}$ Kada je, međutim, riječ o eventualnim podvrstama same poslovice ili "paremiološkim tipovima” (Kekez 1984: 68), njihovi su zaključci znatno manje podudarni. Premda su, kao što su i pokazala najrecentnija razmatranja, ${ }^{5}$ po većini svojih obilježja bliži govorničkim (retoričkim) usmenoknjiževnim oblicima ili žanrovima, blagoslov i kletva u prijašnjim su pregledima i studijama o usmenoj književnosti ${ }^{6}$ tako redovito pridruživani drugim podvrstama poslovice, odnosno izdvajani

2 Poslovicu (izreku) kao jednostavni, odnosno "pretknjiževni" oblik prvi je definirao André Jolles. Prema Jollesu, jednostavne bi oblike trebalo oštro razlikovati od književnih žanrova koji nastaju u kasnijoj, pisanoj književnosti, i to ponajprije stoga jer je riječ o "prvobitnim" načinima izražavanja koji su "složenim" oblicima (žanrovima) poslužili tek kao podloga (Jolles 2000).

${ }^{3}$ U “male (sitne) govorne žanrove” poslovicu je u svojoj knjizi uvrstio Josip Užarević (usp. 2012).

${ }^{4}$ Usp. Čubelić 1988: 296-365; Kekez 1998: 167-176; Dragić 2006: 524-539 i Botica 2013: 488-505.

${ }^{5}$ Misli se, konkretno, na preglede povijesti hrvatske usmene književnosti iz pera Marka Dragića (usp. 2006: 503-523) te Stipe Botice (usp. 2013: 475-488).

${ }^{6}$ Usp. npr. Čubelić 1988: 325-340; Kekez 1984: 66-70 i 1998: 171-174. Zanimljivo, u antologiji Poslovice, zagonetke i govornički oblici Josip Kekez blagoslove i kletve ipak je priključio "govorničkim oblicima" 
kao zasebne paremiološke skupine. Još veću pomutnju izaziva, štoviše, već i samo inzistiranje proučavatelja na razlikovanju paremioloških podvrsta i/ili poslovici srodnih oblika, pri čemu se kao zacijelo najdvojbenija i najšarolikije definirana kategorija nameće ona tzv. paremiologizama. Paremiologizmima tako, primjerice, Josip Kekez (1984: 69-70) drži frazeologizme, poredbe i metafore, koje zatim razlikuje od drugoga paremiološkog "gradiva" ("potpunih" poslovica, izreka, dijaloških poslovica, poslovica-anegdota, kletvi i blagoslova), dok Tvrtko Čubelić jednom od (pod)vrsta poslovice proglašava i "poslovice-frazeologizme", pod kojima podrazumijeva poslovične izreke, poredbe, zaklinjanja i kletve (Čubelić 1988: 334-335). Pavao Mikić i Vjekoslav Suzanić (1994: 7-11) zadovoljit će se tek razlučivanjem ("prave") poslovice od njoj srodnih oblika (sentencije, krilatice, aforizma, maksime, epigrama, slogana, proširene poslovice, poslovične izreke, poslovične usporedbe i protuposlovice), no zato će Stipe Botica - ne navodeći (druge) moguće tipove poslovice - ponovno uvesti kategoriju paremiologizama, i to kao skupni naziv za "sve oblike koji nisu prave poslovice već izričaji koji imaju nepotpunu strukturu poslovice ili su to poslovične sintagme i fraze u kojima se nazire dio poslovičnog izričaja ili dio stiliziranja na način poslovice" (Botica 2013: 491). Pritom će u paremiologizme, iako ih je nešto ranije klasificirao u usmenoknjiževne govorničke oblike, Botica uvrstiti i već spomenute kletve i blagoslove (budući da se, pojašnjava, "dio paremiološkoga blaga nazire u njihovoj strukturi"; isto), dok će im s "područja" pisane književnosti pribrojiti još i aforizme, krilatice, sentencije, poslovične fraze, apoftegme i biblijski mašal (isto).

Očito je, dakle, da su domaći folkloristi prilično daleko od postizanja konsenzusa o tome bi li se i koje konkretno tipove ili srodne oblike moglo uključiti u žanr poslovice, kako bi te podvrste valjalo nazivati, što bi sve trebala obuhvaćati kategorija paremiologizama te koje bi joj, shodno tomu, određenje najbolje pristajalo. Nije pritom upitno da je, prihvatimo li ih kao takve, zaista "teško povući čvrstu granicu između poslovice i njoj srodnih oblika jer ti srodni oblici mogu s vremenom postati poslovice" (Mikić i Suzanić 1994: 11), kao ni to da bi rečene oblike - maksimu, sentenciju, krilaticu, izreku i dr. - stoga možda i najopravdanije (ili makar najmanje pogrešno) bilo motriti kao svojevrsne varijante poslovice. Štoviše, čini se da je na tragu takvog zaključka i dio stranih proučavatelja, koji u srodnim oblicima prepoznaju karakteristično poslovični tip izražavanja (usp. npr. Hoffman 2012: 1122-1123) i stoga predlažu da se, s obzirom na to da se (formom) od poslovica bitnije ne razlikuju, svi redom oni priključe "širem” žanru poslovice (usp. Štěpán 2015: 807-810), odnosno shvate kao "različiti nazivi načelno iste vrste u varijacijama” (Solar 2011: 376). Žanrovski se naziv "poslovica", drugim riječima, očito pokazuje kao dovoljno elastičan da bi se mogao proširiti i na pobrojane srodne forme, a uz to i dalje obuhvaćati različite tipove poslovičnih izričaja (dijaloške poslovice, poslovice-anegdote, frazeologizme itd.), i to posve neovisno od njihova usmeno- ili pisanoknjiževnog podrijetla. Žanr poslovice stoga bi mogao i morao podrazumijevati svaki onaj (jednostavni) oblik, formu ili (pod)žanr koji se bazira na poslovičnom tipu izražavanja, nosi poslovici blisku strukturu i postiže poslovici srodne 
učinke, ${ }^{7}$ i to neovisno od toga iz koje sfere dolazi, je li ostvaren u stihu ili prozi, kolika je njegova starost i kojoj konkretno podvrsti pripada. U tom smislu, podvrstama poslovice i/ili srodnim oblicima možda bi ponajbolje i pristajao upravo zajednički naziv "paremiologizmi”, kojim bi se ne samo s(p)retno naglasila njihova različitost u odnosu na "pravu" poslovicu - proizišlu iz težnje da se doživljeno iskustvo pretoči u kratku i zaokruženu poantu - već ujedno i istaknula pripadnost tih oblika žanru poslovice u širem smislu riječi.

Bez obzira na to kako i što konkretno kategorizirali poslovicom, nepobitna je književnopovijesna činjenica da njezin žanr dobiva na važnosti poglavito od razdoblja humanizma. Zanimanje za poslovicu diljem je Europe naročito bilo izraženo u 16. i 17. stoljeću, kada se (usmenoknjiževne) poslovice počinju skupljati i objavljivati u zasebnim zbirkama, ali i u znatnijoj količini uvrštavati u žanrovski različito obilježena pisanoknjiževna djela. Toj su se "modi" ubrzo priklonili i naši autori, što ponajbolje dokazuje i prva hrvatska rukopisna zbirka poslovica Proričja slovinska iz 1697., koju je sredinom 17. stoljeća najvjerojatnije započeo sastavljati Dubrovčanin Đuro Matijašević, a potom je konačno redigirao njegov nećak Ivan Marija Matijašević. ${ }^{8}$ Trag kreativnog uvrštavanja (usmenih) poslovica u tekstove pisane književnosti moguće je, pak, pratiti još od pjesama Šiška Menčetića i Džore Držića, preko opusa Marina Držića, Zoranića, Hektorovića i Barakovića, pa sve do djela Gundulića, Palmotića, Đurđevića i Frankopana, koji, između ostalog, piše i zbirku poslovica Šentencije vsakojaške. ${ }^{9}$ Pritom je neobično velik broj poslovica našao svoje mjesto u djelima koja pripadaju ciklusu tzv. zrinijada, odnosno pretežno narativnih tekstova u kojima se tematizira junačka pogibija bana Nikole Šubića Zrinskog i njegove malobrojne kršćanske vojske pod mađarskom utvrdom Siget (Szigetvár) u ljeto 1566. godine. Izuzme li se kronika Podsjedanje i osvojenje Sigeta (1568) Ferenca Črnka, mnogobrojne poslovične izričaje proučavatelji su uočili već u povijesnom epu Vazetje Sigeta grada (1584) Barne Karnarutića (Kekez 1987: 124-126), a niz poslovica - iako je zapravo riječ o hrvatskom prijevodu i adaptaciji devet godina starijega mađarskog epa Szigeti veszedelem njegova brata Nikole - uvrstio je i Petar Zrinski u svoju epsku pjesmu Obsida sigecka, objelodanjenu 1660. u sklopu lirsko-epskoga zbornika Adrijanskoga mora Sirena. Iznimka po tom pitanju nije ni četverodijelna žanrovski hibridna zrinijada Odiljenje sigetsko znamenitoga senjskog pjesnika, polihistora, jezikoslovca, povjesničara i tiskara Pavla Rittera Vitezovića (1652. - 1713.).

U povijesti hrvatske književnosti Pavao Ritter Vitezović izdvaja se kao jedan od prvih autora koji je pokazivao otvoreno divljenje spram stvaralaštva bespismenih društvenih slojeva. Dokaz su tomu ne samo njegovi zapisi autohtonih usmenoknjiževnih ostvarenja poput bugaršćice o bitci na Krbavskom polju10 i fragmenta "narodne" lirske pjesme pridodane povijesnoj raspravi Natales D. Ladislavo R. Slavoniae Apostolo Restituti (1704) već i njegova svjedočanstva o pjevanju usmenih pjesama o hrvatskome banu Ivanu Karloviću,

7 Podrobnije o konkretnim obilježjima žanra poslovice u Kekez 1984; Čubelić 1988: 303-343; Mikić i Suzanić 1994: 7-37; Užarević 2012: 203-212 i Botica 2013: 488-500.

${ }^{8}$ Rukopis u kojem se danas nalaze Proričja slovinska poznatiji je kao tzv. Dubrovački rukopis.

${ }^{9}$ Podrobnije o tome u Kekez 1984: 25-49.

${ }^{10}$ Vitezovićev zapis spomenute bugaršćice vjerojatno datira iz 1682. (usp. o tome u Kekez 1992: 54). 
ali i pokušaji prilično slobodnog tumačenja nekih folklornih tekstova (primjerice, znamenite romance Marina kruna)..$^{11}$ Osim što je, također, i brojna svoja djela protkao različitim formalnim i sadržajnim postupcima usmene književnosti, a kao predložak za hagiografiju Vita et Martyrium B. Vladimiri Croatiae Regis iz 1705. uzeo folklornim posebnostima bremenitu legendu o blaženom kralju Vladimiru iz Ljetopisa popa Dukljanina (12. st.), izrazitu je sklonost Vitezović gajio i prema (usmenoknjiževnim) poslovicama. Ponajbolje to potvrđuje zbirka osmerački ispjevanih "priričja" Priričnik aliti razliko mudrosti cvitje iz 1703., ${ }^{12}$ u koju su uvrštene redom sve poslovice (njih oko tristo) što ih je Vitezović od 1697. - pod istim naslovom - objavljivao u sklopu svojih pučkih kalendara.

Da se, naprotiv, Vitezovićev interes za žanr poslovice nije svodio na tek zapisivanje "narodnih" poslovica na vlastite se oči (i uši) imao prilike uvjeriti već i njegov suvremenik i veliki prijatelj Janez Vajkard Valvasor. Taj kranjski barun i polihistor, u čijem je dvorcu u Bogenšperku mladi Vitezović boravio tijekom 1676. i 1677. godine, ${ }^{13}$ u autobiografskim se dionicama svojega zamašnog djela Slava vojvodine Kranjske (1689) prisjetio, između ostalog, i prijateljeve nevjerojatne vještine u smišljanju originalnih kratkih poslovica (sentencija), koje je u gotovo svakoj prilici bio spreman "izbaciti" iz sebe (usp. Kovač 1973: 118-119)..$^{14}$ Uz to, kao nepobitan je dokaz zadivljenosti oblikom poslovice ostao iza Vitezovića i priručni rukopisni zbornik Varia extracta et notitiae (danas pohranjen u fondu NSK-a), u koji je, sluteći da će mu one kad-tad zatrebati, vlastoručno niz godina prepisivao izreke i poslovice iz tekstova mnogih antičkih (podjednako starogrčkih i starorimskih) autora - Epikteta, Auzonija, Juvenala i dr. - te nekih šesnaesto- i sedamnaestostoljetnih njemačkih pisaca. ${ }^{15}$ Kao i poslovice iz njegovih pučkih kalendara (a onda i iz spomenutoga Priričnika), ni one uključene u druga njegova (književna) djela na hrvatskom jeziku stoga se ne mogu naprečac proglasiti autohtono usmenoknjiževnima, već svakako valja računati i s njihovim (možebitno) pisanoknjiževnim i/ili autorskim porijeklom. Ostavi li se po strani kronikalni prikaz hrvatske i svjetske povijesti Kronika aliti spomen vsega svieta vikov iz 1696., u kojem su poslovični izričaji sasvim izostali, vrijedit će to i za poslovice što ih je Vitezović utkao u dvanaesteračku poslanicu Dobro plemenitomu i viteškomu gnu Ferencu Ivanoviću od Šćitara (1682), fragmentarno sačuvanu knjigu gatalica Lado horvatski iliti Sibila (vjerojatno iz 1701.), osmeračku pjesmu Senjčica $(1704)^{16}$ te naročito za one u Odiljenju sigetskom (1684).

\footnotetext{
${ }^{11}$ Detaljnije u Bošković-Stulli 1978: 208-210.

${ }^{12}$ Naslov potječe od riječi "priričje”, odnosno "prirječje”, koja je zapravo doslovni (staro)hrvatski prijevod latinske riječi "proverbium” (poslovica). "Priričnik” bi, dakle, značio "zbirka poslovica” (usp. Kekez 1984: 8).

${ }^{13}$ O Vitezovićevu prijateljevanju s Valvasorom više u Klaić 1914: 9-38.

${ }^{14}$ Doduše, spomenuti podatak valja uzeti s dozom opreza budući da se u knjizi Tite Kovač Valvasorove autobiografske bilješke počesto obilno nadopunjuju fikcionalnim dodacima.

${ }^{15}$ O ovome zborniku opširnije u Putanec i dr. 1952: 32 i Kosić 2013: 36-37.

${ }^{16} \mathrm{Na}$ "kratke sentence s didaktičnom namjenom" u Senjčici pozornost je svojedobno skrenuo Branko Krmpotić (usp. 1970: 625-630).
} 


\section{OD KORICA DO KORICA}

lako je, s tematskog aspekta, riječ o "punopravnom" pripadniku ciklusa hrvatskih zrinijada, Odiljenje sigetsko (1684)17 Pavla Rittera Vitezovića po većini svojih sadržajnih i formalnih posebnosti predstavlja ujedno i izuzetak u tome nizu. Za razliku od ostalih, mahom epskih zrinijada, tursko zauzeće i pad Sigeta u Odiljenju su, naime, prikazani kao doživljaj različitih - živih i personificiranih - likova koji su u njemu neposredno (ban Zrinski, grad Siget itd.) ili posredno (kralj, vila Hrvatkinja i dr.) sudjelovali. U njihovim iskazima, koji se nižu kao zasebne pjesme, miješaju se pritom obilježja mnogobrojnih žanrova, pa su osim onih pisanoknjiževnih (tužaljke, poslanice, epitafi itd.) i rubno književnih (primjerice, molitve i govori), obilno tako zastupljeni i elementi usmenoknjiževnih žanrova (usmenih epskih pjesama, bugaršćica, naricaljki), ali i neki retorički (blagoslovi i kletve) te jednostavni oblici usmene književnosti (zagonetke i poslovice) u cijelosti. Među navedenim žanrovima svojom se brojnošću, odnosno gotovo ravnomjernom zastupljenošću u svim četirima dijelovima teksta ističu upravo poslovice i paremiologizmi, na prisutnost kojih su u nekoliko ranijih navrata već upozorili pojedini proučavatelji. ${ }^{18}$ I premda, kao što će se doskora i potvrditi, sve poslovice u Odiljenju nisu usmenoknjiževnoga porijekla, zbog preglednosti nužno ih je razlikovati prema folklorističkim kriterijima, odnosno značenjski razvrstavati u nekoliko unaprijed zadanih tzv. "semantičkih polja", 19 kao što to s "narodnim" poslovicama obično i čine stručnjaci za usmenu književnost.

Vitezovićeva nakana da Odiljenje sigetsko (1684) protka poslovicama doslovno "od korica do korica" uočava se već u paratekstualnim njegovim dijelovima, obilno ispresijecanima poslovičnim izričajima. Primjerima vrlo bliskima autohtonim usmenim poslovicama obogaćen je tako već predgovor $K$ čtavcu prvoga izdanja Odiljenja, pri čemu prvu od sveukupno tri poslovice (u formi distiha u dvostruko rimovanom dvanaestercu) Vitezović unosi u prozni segment, dok su preostale dvije dio nenaslovljene osmeračke pjesme kojom se predgovor i zaključuje. Promotre li se one u značenjskome (smisaonom) kontekstu, pokazat će se kako dvanaesteračka poslovica "Človik najdičnije svoju halju nosi, / a što doma nije, to se vani prosi" i osmeračka "dobrim jezik zal ne udi" potvrđuju svoju pripadnost sociološkome, a druga osmeračka "pod nebom ne znam gdo je / ki svim more ugoditi",

\footnotetext{
${ }^{17}$ Drugo izdanje Odiljenja - s izmijenjenom naslovnicom, posvetom i predgovorom - Vitezović tiska već sljedeće, 1685. godine u Beču, a nedavno otkriveno treće (s novim naslovnim listom i posvetom) 1695. u zagrebačkoj Zemaljskoj tiskari kojom je tada upravljao. Podrobnije o potonjem izdanju u Budišćak 2016.

${ }^{18}$ lako većinom uzgredno, o poslovicama u Odiljenju više je puta bilo riječi u posljednjih tridesetak godina (usp. Kekez 1987: 126-129; Mikić i Suzanić 1994: 154; Kolumbić 2005: 345-348 i Hranjec 2016: 28-29).

${ }^{19}$ Usmene je poslovice u više od 150 značenjskih polja svojedobno razvrstao još čuveni devetnaestostoljetni ruski leksikograf i etnolog Vladimir Pal' (usp. Užarević 2012: 204), a u nas se za takav način klasificiranja poslovica najodlučnije opredijelio Josip Kekez. Kekez tako poslovice dijeli u niz skupina prema unaprijed određenim "semantičkim poljima" (povijesno, filozofsko, etnološko, sociološko, religijsko, psihološko, antropološko, politološko, profesijsko i dr.) te pritom napominje i kako bi se svako od njih dodatno još moglo razdijeliti na podskupine ili "reme" (filozofsko značenjsko polje tako bi, primjerice, uključivalo reme "sudbina", "smrt”, "vrijeme”, "život”, "čovjek” itd.). Opširnije u Kekez 1984: 57-70.
} 
zbog aludiranja na urođeno karakterno čovjekovo obilježje, psihološkome semantičkom polju.

Poslovice nisu izostavljene ni iz predgovora Prijaznivi štavče! drugoga, bečkog izdanja Odiljenja (1685). S obzirom na to da je i ovaj (para)tekst koncipiran prema modelu identičnom onome predgovora prethodnom izdanju (prozni segment koji završava pridruženom lirskom pjesmom), poslovice je iznova moguće locirati kako unutar prozne dionice (distih u dvostruko rimovanom dvanaestercu) tako i u sklopu lirske pjesme Učinitelj knjigam (tri primjera). I dok poslovica uvrštena u prozni dio predgovora (“Čim ki veće ima, već želi imati, / A ki ništar nima, otkud će što dati?") teži ukazati na općepoznatu čovjekovu sklonost prekomjernom stjecanju (psihološko semantičko polje), one sadržane u dvanaesteračkoj pjesmi najbliže su sociološkom ("Dosta j' da te hvale ljudi od razbora, / a pameti male ne boj se prikora" i “v dobru se ne vznesi, nit se $v$ zlu ražali”), odnosno filozofskom polju ("Nima se prevzeti komu srića dvori, / kad srića odleti, nisko se obori”). Za razliku od predgovora prvom i drugom izdanju, u oduljoj proznoj posveti nedavno otkrivenoga trećeg Vitezovićeva izdanja Odiljenja (1695) nije se našlo mjesta ni za jednu poslovicu, što je, po svemu sudeći, posljedica činjenice da je ono bilo namijenjeno posve drugačijem krugu čitatelja, i to isključivo onima iz najviših društvenih slojeva, a ne više (i) slabije obrazovanoj publici, kao što je to bio slučaj s prijašnjim izdanjima. ${ }^{20}$

Što se, pak, (u sva tri izdanja nepromijenjenoga) teksta "spjeva" tiče, već prvi se njegov "dil" izdvaja brojnošću izuzetno upečatljivih poslovica i poslovičnih nizova o sveprisutnoj razarajućoj snazi smrti ("Ni človik ni dite smrti vteć ne more, / da ga prem sve šćite vode, ognji, gore. / Smrti se pokore poglavniki svita, / svakim ona more, s nijednim ne pita", I: 265-268; ${ }^{21}$ "Pod nje vlasti dika i jakost opada, / od vika do vika smrt na svitu vlada", I: 277-278; "Koje godar tilo na 'vom svitu hodi, / il knjasto il cilo, smrt na svoj cilj vodi. / Zna človik, gdi rodi njega mila mati, / al gdi ga smrt zgodi, to ne more znati”, I: 301-304; "Mladosti nit roda ljuta smrt ne gleda", I: 383; "Svakomu umriti jednuč suđeno je, / nigdor ne m're biti prost od smrti svoje", I: 407-408; "Smrti se sakriti ni moći človiku, / a svakom dobiti smrćom ni moć diku”, I: 599-600). Istomu, filozofskom semantičkom polju pripadaju i pobrojanim primjerima srodne poslovice o hirovitosti sreće ("Srića ima ćudi i dvisto i tristo, / sad udi, sad prudi, minja misto", III: 99-100; “Tako srića svita nestanovita je: / što dugo obita, to dugo ne daje", IV: 51-52), dok spoznaju o destruktivnoj prirodi podjednako nepostojane sreće i vječno vrebajuće smrti donose poslovice o prolaznosti, mahom situirane u posljednjemu (nadgrobničkom) dijelu Odiljenja ("Tako svita stvari (kot tekuće vode), / časti i timari i krune prohode", IV: 13-14; "Ni veruvat diki svita, da prem sije", IV: 28; "Suprot smrti ni lik, srića vik ne služi", IV: 30; "Roka nigdor svoga previdit ne more, / srića ni stanovita, / sve stvari ovoga svita se pokore / smrti, ka sve hita”, IV: 219-222).

Poslovice u Odiljenju nerijetko se dotiču i važnosti junačkoga umiranja za "više ideale", što će reći da u podjednakoj mjeri ulaze i u religijsko i u filozofsko semantičko polje ("za

\footnotetext{
${ }^{20} \mathrm{O}$ vjerojatnoj publici trećega Vitezovićeva izdanja Odiljenja sigetskog opširnije u Budišćak 2016.

${ }^{21}$ Rimski broj upućuje na "dil", a arapski na stihove unutar navedenoga dijela.
} 
Boga umriti i za dom slavno je", I: 316; "s krvjom vitez diku kupi, / iz zemlje na nebo stupi", IV: 397-398), dočim bi isključivo antropološkom polju pripadala poslovica kojom sin Juraj banu Zrinskom u pjesmi Ban sinu pokušava ukazati na važnost dobroga glasa ("pozitivne reputacije") proizišlog iz hrabrih (ratničkih) djela ("Da ima sve stvari i svega zadosti, / ki za glas ne mari, vik žive v tamnosti”; I: 581-582). Poslovice poput "što suđeno je, ono mora biti" (I: 338), "Život uživati Bog človiku poda, / al do kih dob, znati to mu Bog ne doda" (I: 381-382) i “telo zemlja biva, a Bog dušu primi” (II: 110) - kojih se velik broj inačica može pronaći i među do danas zabilježenim autohtonim narodnim mudrostima - tipični su, pak, izdanci religijskoga polja, a na razmeđu religijskoga i filozofskoga značenjskog polja valjalo bi smjestiti poslovice poput "Navike živiti ovdi se ne može, / zemlja mora biti 'z kosti, 'z mesa, 'z kože" (I: 492-493) te "umrit je človiku” (II: 343).

Pored navedenih sadržajnih ishodišta (smrt, sreća, prolaznost, rat), nešto skromnija će količina poslovica i paremiologizama u Odiljenju prizivati i sasvim drugačiji krug životnih tema poput (ne)sloge, opreznosti, ljubavi, tuge i bogatstva. Filozofsko semantičko polje obuhvaća tako poslovice o nepovoljnim životnim okolnostima ("ni jelvi izrasti srid ognja ni moći”, II: 154; "tilo truda sito izlahka umira”, II: 187), dok sociološkome (možda djelomice i antropološkom) polju pripadaju poslovični izričaji o pogubnosti nesloge ("Ruše se, ne stoje gradi prez složnosti”, II: 613; "Zla ta naša sloga od naravi stare / razpušća orsaga nam kotare", III: 197-198). Iz psihološkog polja valja izdvojiti dvije poslovice o emotivno-mentalnoj (ne)uravnoteženosti i (ženskoj) tuzi što ih izriče ucviljena Sofija naričući nad poginulim Alapićem u pjesmi Gospodična Sofija i oral ("glavi prez srca ni, a srcu prez glave", II: 866; "ni žalosti sila veća neg u ženi”, II: 898), zatim poslovicu o ozbiljnosti ljubavi ("Kot pri ognju dima, gdi su drva huda, / posla ljubav ima i kot ruda"; III: 293-294) te iznimno zanimljivo poslovično ismijavanje bogataške sebičnosti ("Al ki su bogati, gospoda takoje, / sami uživati sve nastoje"; III: 103-104), koje je u potpunosti na tragu poslovice o pretjeranom gomilanju materijalnih dobara iz predgovora Prijaznivi štavče!!

Posebnu pozornost svakako zaslužuju dva i više nego zanimljiva poslovična izričaja uklopljena u treći "dil" Odiljenja sigetskog, koji zapravo predstavljaju tipične primjere tzv. poslovica s izvedbenim sponama. ${ }^{22}$ Riječ je o, konkretno, onim poslovicama kojima su pridodani očiti izvedbeni signali, odnosno u kojima jedan dio "teksta” izrijekom upućuje na govorno (usmenoknjiževno) porijeklo ili frekventnost u svakodnevnoj razgovornoj uporabi. Ispitujući vilu Jeku o pojedinostima turskog zauzeća Sigeta, putnik u pjesmi Putnik i Jeka tako hotimice umeće (odvajajući ih zagradama) jasne aluzije na folklorno podrijetlo najprije u poslovicu "Ludo je prositi (veli se rič zdavno), / što ni moć dobiti." (III: 21-22), a zatim i onu "Čim već blagoviti človik (kot se veli), / tim veće želiti može li? O, želi!" (III: 89-90). Promotre li se, međutim, iz perspektive semantičkih polja, pokazat će one ipak dva različita lica, pa dok bi prva od njih podjednako mogla biti uvrštena i u sociološko i u antropološko

${ }^{22}$ Frazom "poslovice s izvedbenim sponama" ovaj tip poslovica naziva Josip Kekez (usp. 1996b). 
polje, druga je najbliža psihološkom polju, a uz to se - s obzirom na svoju "pitalačku" formu - može klasificirati i u podvrstu tzv. dijaloških ili poslovica-pitalica. ${ }^{23}$

Utvrđena (mnogo)brojnost poslovica u Odiljenju sigetskom nipošto, kako se čini, nije mogla biti slučajna. Iščitaju li se pažljivije dijelovi "spjeva” protkani poslovicama, sam će se od sebe nametnuti zaključak da za poslovičnim izričajima različitoga podrijetla Vitezović ponajprije poseže želeći što efektivnije poentirati iznesene misli i zapažanja, a sve u cilju približavanja "recepcijskoj logici" i onog dijela publike s ponešto skromnijom (književnom) naobrazbom. Da je tomu zaista trebalo biti tako najlakše je razabrati upravo iz onih dionica u kojima kazivanja pojedinačnih govornika prelaze u razmatranja o varljivosti sreće, prolaznosti svega zemaljskog ili važnosti herojskog umiranja za Boga, kralja i domovinu, koje Vitezović - ne bi li ih smisaono zaokružio i uopće snažnije naglasio - dosljedno "ovjerava" značenjem srodnim iskustvenim tvrdnjama. Pa kada tako, primjerice, moralistička razmišljanja o časnoj pogibiji na bojnome polju prožima nizom poslovica na temu prolaznosti i neizbježnosti smrti, Vitezović zapravo koristi prokušanu strategiju pomoću koje će "visoku" (elitnu) književnost i njezine ideje lakše "približiti puku, ne bi li njezin utjecaj bio veći" (Pavličić 2007: 283). Na kraju krajeva, s identičnom nakanom i na gotovo isti način na koji ih rabi i u sva četiri “dila” poslovice on uvrštava i u predgovore prvih dvaju izdanja, u kojima također pojedina ključna mjesta (primjerice, zapažanja o pogubnoj raširenosti tuđica u hrvatskom jeziku ili suvremenoj gramzivosti domaćih bogataša) teži značenjski potvrditi u zgusnutoj poučnoj formi kako bi njihove zaključke učinio pristupačnima podjednako učenoj, ali i jedva pismenoj publici. I baš kao što se, u svome izvornom egzistencijskom okružju, poslovice "prema potrebi i situaciji ubacuju u (raz)govorni proces ili kontekst" (Užarević 2012: 208), tako i Vitezović paremiologizme i poslovice donosi upravo na mjestima čiji je sadržaj nužno dodatno istaknuti kako bi i čitatelji različitoga profila bili u stanju razumjeti njegovu važnost, a onda ga i - transformirana u kratku poslovičnu poantu - mogli lakše upamtiti, pa i, po potrebi, primijeniti.

Sveprisutnost poslovičnih izričaja u Odiljenju sigetskom, ipak, samo je napola uvjetovana brojnošću refleksivnih dionica. Naime, uvjerljivo najveći broj poslovica u "spjevu" ima svoje idejno ishodište u problemima nestalnosti i prolaznosti, koji i jesu u neposrednoj vezi s njegovim temeljnim tematskim usmjerenjem opjevavanju višestrukih rastanaka. Budući da gotovo opsesivno isticanje varljivosti sreće, trošivosti ovozemaljskih dobara i općenito pesimistički pogled na čovjekovu sudbinu pripadaju među ključna barokna sadržajna uporišta, koja su se nerijetko pojačavala i sentencijskim poentiranjima, jasno je zašto Vitezovićevo inzistiranje na poslovicama o neizbježnosti smrti i kolebljivoj sreći treba ujedno motriti i kao "ukus toga vremena koje je bilo bremenito baroknim recidivima" (Kolumbić 2005: 346). Neće, osim toga, biti slučajno ni to što je mnogim poslovicama (sentencijama) proizišlima iz identičnih tematskih krugova svoju Obsidu sigecku - neposrednu prethod-

${ }^{23}$ O poslovicama-pitalicama detaljnije u Kekez 1984: 68. 
nicu i važan intertekstualni oslonac Odiljenja ${ }^{24}$ - protkao i Petar Zrinski, ${ }^{25}$ što bi također najopravdanije bilo držati odzrcaljenjem "duha vremena" s kojim se s(p)retno ispreplelo bogato iskustvo recipiranja usmenoknjiževnih tvorevina.

\section{NEKOLIKO IZVORA}

Činjenica kako su se u nas, ali i diljem sedamnaestostoljetne Europe mnoga književna djela obilno punila poslovičnim iskazima, a uz to su i paralelno sastavljane i izdavane i zasebne kolekcije poslovica, lako bi mogla navesti na pogrešne zaključke o njihovu vjerojatnom podrijetlu. Da je samo djelomice bila riječ o izvornim "narodnim" poslovicama ili, pak, književnim preradama istih uvjerljivo će potvrditi i opus Pavla Rittera Vitezovića, u kojem se kao svojevrsna "kruna" autorove zaokupljenosti ovim žanrom izdvaja već spomenuta zbirka Priričnik aliti razliko mudrosti cvitje (usp. 1976). lako namijenjena pretežno skromnije obrazovanim čitateljima, u Vitezovićevoj knjizi, utvrdila su najrecentnija istraživanja, mjesta se našlo samo za dio (stiliziranih) poslovica originalno usmenoknjiževne provenijencije, dok znatan njihov broj zapravo otpada na poslovične izričaje posuđene iz raznolike - svjetovne i vjerske - lektire te, dakako, one kojih se autor samostalno domislio.

Ukoliko bi se, konkretno, u ciklus usmenih poslovica tako mogli ubrojiti svi oni primjeri koji se dotiču omiljenih "folklornih" tema - vremena, obitelji, prijateljstva, odnosa života i smrti, bogatstva i siromaštva, sloge i nesloge, ludosti i mudrosti i dr., većina preostalih bi poslovica okupljenih u Priričniku (a prvotno objavljenih u Vitezovićevim kalendarima), tvrde proučavatelji, svoj izvor trebala imati u djelima onodobnih filozofskih autoriteta te Bibliji i drugim teološkim spisima. Zastupljenošću se pritom ističu poslovice sadržajno oslonjene na postulate neostoicističke filozofije, koju je u svojim djelima razradio šesnaestostoljetni belgijski filolog Justus Lipsius i koja se ubrzo nametnula kao ideološko ishodište europskoga baroka, ${ }^{26}$ a mahom je riječ o onim primjerima u kojima se glorificiraju moralne vrline ("kripost"), kritizira ljudska opsjednutost novcem, progovara o odnosu zakona prema malom čovjeku ili ističe važnost domoljublja, naročito u ratnim okolnostima. Priričnik donosi i nemali broj biblijskih poslovica, redom fokusiranih na moralističko pretresanje teme čovjekova odnosa prema Bogu, koje, zajedno s onima neostoicističkog podrijetla, najjasnije daju do znanja da je primarna svrha zbirke bila naglašeno edukativna. Vitezović se, drugim riječima, svojom kolekcijom poslovica očigledno namjeravao približiti poglavito skromnije (gdjekad i jedva) obrazovanoj publici ne bi li joj prenio neka suvremena znanja i ideje, i to pomiješana s tradicionalnim vrijednostima, odnosno uklopljena u prepoznatljivo usmenoknjiževne formalne okvire. Ti okviri, dakako, nisu podrazumijevali samo odabir poslovice kao jednoga od omiljenih i gotovo sveprisutnih (izvorno) folklornih žanrova

\footnotetext{
${ }^{24}$ Opširnije o intertekstualnim sponama između Obside i Odiljenja u Pavličić 2007: 273-279.

${ }^{25}$ Slično kao i u Vitezovićevoj zrinijadi, i u onoj Petra Zrinskoga poslovice su najzastupljenije upravo u refleksivnim dijelovima, situiranima pretežno na počecima pjevanja, gdje se iznose neka opća razmatranja vezana uz fabulu konkretnoga "dela".

${ }^{26}$ Podrobnije o neostoicističkoj baroknoj filozofiji u Oestreich 2008: 13-131 i Simpson 1991: 45-49.
} 
već i opredjeljenje za stih osmerac koji je izrastao upravo iz usmene književnosti i koji je, kao takav, mogao jamčiti Vitezoviću da će makar neke od poslovica iz Priričnika prijeći u usmeni “optjecaj” i tako nastaviti svoju egzistenciju (usp. Hrgić 2015: 42-72).

A da elitna kultura vrlo lako može prodrijeti u onu pučku Vitezović je, čini se, shvatio već i nekoliko desetljeća prije objavljivanja Priričnika. Naime, osim što će Priričnik postati prvom u nas tiskanom knjigom (usmenih) poslovica (usp. Bošković-Stulli 1978: 183-184), a kasnije se prometnuti i u "najčešće upotrebljivanu knjigu hrvatskoga poslovičnog blaga" (Botica 2013: 497), njegova se važnost krije i u činjenici da je u njemu moguće zateći i određen broj "priričja" koja bi se mogla shvatiti kao svojevrsne varijante poslovica uvrštenih u Odiljenje sigetsko. lako je poslovica s takvom tematskom orijentacijom u zbirci svega tek nekoliko, vrijedi zabilježiti one koje progovaraju o ljepoti junačkog umiranja za domovinu (“Kako lipo jest živiti, / za dom dično jest umriti”; Vitezović 1976: 478), nestalnosti sreće i inih zemaljskih stvari ("Srića i stvar vsaka svita / nijedna ni stanovita"; isto: 484), neizbježnosti smrti ("Ludo se je bojat smrti / s kom se vsaki rođen prti”; isto: 482; "Svit se vrti, svit obraća: / v samoj smrti vsih je plaća”, isto: 484;) te potrebi održavanja dobre, po mogućnosti na časnim i hrabrim djelima izgrađene reputacije ("Ako ti prem vse izgine, / pošten glas te nek ne mine"; isto: 478). Malobrojnosti usprkos, pobrojani su primjeri i više nego uvjerljiv dokaz da je - računajući (u prva dva izdanja) na vrlo široku, no pretežno pučku publiku - Vitezović već Odiljenje premrežio, između ostalih, i značenjski gotovo identičnim mudrim izrekama utemeljenima na tada modernim idejama i spoznajama, što će reći (i) onim poslovicama koje definitivno nije mogao pronaći na prostoru (onodobne) usmene književnosti.

Ima li se ovo na umu, nipošto ne bi smjelo iznenaditi ni to što je većinu poslovica iz Priričnika moguće uvrstiti upravo u ona semantička polja - filozofsko, sociološko, psihološko i religijsko - kojima su najbliže i gotovo sve poslovice što ih sadrži i Odiljenje sigetsko (usp. Hrgić 2015: 47). S druge, pak, strane, unatoč činjenici da je - kao i kada je riječ o onima iz Priričnika - "točan izvor Vitezovićevih izreka nemoguće precizirati” (isto), samo za dio bi se poslovica uključenih (i) u Odiljenje sa sigurnošću moglo tvrditi da su usmenoknjiževnoga porijekla. Ponajprije se to odnosi na poslovice izrasle iz već pobrojanih općeživotnih, usmenoj književnosti naročito bliskih tema (ljubav, sloga, sudbina, ludost i mudrost, bogatstvo i siromaštvo itd.), a gotovo nimalo ili samo djelomično na one koje proizlaze iz tipično baroknih motiva hirovite sreće, propadljivosti materijalnih dobara, junačkog umiranja na bojnom polju i sl. Budući da je redom riječ o pitanjima koja su pretresali tada iznimno popularni tekstovi Justusa Lipsiusa, posve je jasno da bi potraga za njihovim podrijetlom ponajprije trebala krenuti upravo od radova toga glasovitog neostoicističkog filozofa.

Poslovice, pak, s izraženom moralnom poukom i naročito one koje se dotiču odnosa čovjeka i Boga svoj bi izvor očigledno trebale imati u Bibliji (usp. npr. Kaštelan i Duda 2003), ${ }^{27}$ a možda i u nekim drugim teološkim spisima koje je - kao nekadašnji isusovački

${ }^{27}$ Pavao Mikić i Vjekoslav Suzanić u zbirci Biblijske poslovice u Hrvata izdvajaju četiri biblijske poslovice iz Odiljenja. Tri bi se od njih ("Bogu se v ruke dat, jer nam je umriti”, I: 491; “Navike živiti ovdi se ne može, / zemlja mora biti 'z kosti, 'z mesa, 'z kože”, I: 492-493 i “Smrti se sakriti ni moći človiku, / a svakom dobiti smrćom ni 
đak - Vitezović u svojoj mladosti jamačno čitao. ${ }^{28}$ Pridoda li se spomenutima još i poneka autorska mudra izreka, postat će bjelodano da poslovice u Odiljenju nisu u cijelosti rezultat Vitezovićeva sustavnog zapisivanja i prerađivanja usmenoknjiževnoga poslovičnog blaga, iako je upravo izravni susret s tim blagom očito ponajviše utjecao na njegovu sklonost poslovicama. Kako bilo, poslovice u Odiljenju sigetskom, ali i one zastupljene u drugim djelima iz bogatoga stvaralačkog opusa Pavla Rittera Vitezovića stoga ostaju i više nego intrigantnom temom dostojnom znatno iscrpnijih istraživanja, kako onih iz folklorističke tako i onih iz književnopovijesne, a onda svakako i komparatističke perspektive.

\section{NAVEDENA LITERATURA I IZVORI}

Bošković-Stulli, Maja. 1978. “Usmena književnost”. U Usmena i pučka književnost. Maja Bošković-Stulli i Divna Zečević, ur. Zagreb: Liber, Mladost, 7-353.

Botica, Stipe. 2011. Biblija i hrvatska tradicijska kultura. Zagreb: Školska knjiga.

Botica, Stipe. 2013. Povijest hrvatske usmene književnosti. Zagreb: Školska knjiga.

Budišćak, Vanja. 2016. “Treće Vitezovićevo izdanje Odiljenja sigetskog (1695.)”. Kaj 49/5-6: 82-104.

Čubelić, Tvrtko. 1988. Povijest i historija usmene narodne književnosti. Zagreb: vlastito izdanje.

Dragić, Marko. 2006. Poetika i povijest hrvatske usmene književnosti. Split: Filozofski fakultet Sveučilišta u Splitu.

Hoffman, Daniel. 2012. "Proverb". U The Princeton Encyclopedia of Poetry and Poetics. Roland Greene i Stephen Cushman, ur. 4. izdanje. Princeton i Oxford: Princeton University Press, 1122-1123.

Hranjec, Stjepan. 2016. "Sigetsko odiljenje kao književna tema". U Stjepan Hranjec, gl. ur. Hrvatski kajkavski kolendar 2016. Čakovec: Ogranak Matice hrvatske, 22-32.

Hrgić, Danijel. 2015. Kultura medija i medij kulture. Kalendari Pavla Rittera Vitezovića. Zagreb: Filozofski fakultet Sveučilišta u Zagrebu (diplomski rad).

Jolles, André. 2000. Jednostavni oblici. Zagreb: Matica hrvatska.

Kaštelan, Jure i Bonaventura Duda, ur. 2003. Biblija. Stari i Novi zavjet. Zagreb: Kršćanska sadašnjost.

Kekez, Josip. 1984. Poslovice i njima srodni oblici. Zagreb: Zavod za znanost o književnosti Filozofskog fakulteta Sveučilišta u Zagrebu.

Kekez, Josip. 1987. Usmeno-pisani književni suodnosi. Nikšić: Univerzitetska riječ.

Kekez, Josip. 1992. Hrvatski književni oikotip. Zagreb: Zavod za znanost o književnosti Filozofskog fakulteta Sveučilišta u Zagrebu.

Kekez, Josip. 1996a. "O govorničkim oblicima”. U Josip Kekez, prir. Poslovice, zagonetke i govornički oblici. Zagreb: Matica hrvatska, 281-288.

Kekez, Josip, prir. 1996b. Poslovice, zagonetke i govornički oblici. Zagreb: Matica hrvatska.

moć diku”, I: 599-600) pritom moglo povezati s biblijskom poslovicom “Tko se rodi, onaj će i umrijeti” (Mudr 7, 6), a ona "telo zemlja biva, a Bog dušu primi" (Il: 110) najvjerojatnije je odjek znamenite izreke "Prah si, u prah ćeš se vratiti" (Post 3, 19). Usp. Mikić i Suzanić 1994: 154.

${ }^{28}$ Doduše, kao što su to potvrdila i istraživanja naših folklorista, dio biblijskih poslovica apsorbirala je i usmena književnost, gdje su one nastavile cirkulirati sve do naših dana (usp. Botica 2011: 100-108), a oveći broj njih zastupljen je i u Lipsiusovim tekstovima (o kršćanskoj podlozi neostoicizma u Oestreich 2008: 13-56). 
Kekez, Josip. 1998. "Usmena književnost”. U Uvod u književnost. Zdenko Škreb i Ante Stamać, ur. 5. izdanje. Zagreb: Nakladni zavod Globus: 133-192.

Klaić, Vjekoslav. 1914. Život i djela Pavla Rittera Vitezovića (1652. - 1713.). Zagreb: Matica hrvatska.

Kolumbić, Nikica. 2005. Poticaji i nadahnuća. Zagreb: Dom i svijet.

Kosić, Ivan. 2013. Pavao Ritter Vitezović u Zbirci rukopisa i starih knjiga Nacionalne i sveučilišne knjižnice u Zagrebu. Zagreb: Nacionalna i sveučilišna knjižnica.

Kovač, Tita. 1973. Spomini barona Valvasorja. Ljubljana: Cankarjeva založba.

Krmpotić, Branko. 1970. "Vitezovićeva senjska i pomorska tematika”. Pomorski zbornik 8: 613-632.

Mikić, Pavao i Vjekoslav Suzanić. 1994. Biblijske poslovice u Hrvata. Zagreb, Zadar: Školska knjiga, Hrvatski institut za liturgijski pastoral.

Oestreich, Gerhard. 2008. Neostoicism and the Early Modern State. Cambridge: Cambridge University Press.

Pavličić, Pavao. 2007. Epika granice. Zagreb: Matica hrvatska.

Putanec, Valentin i dr., ur. 1952. Djela Pavla Vitezovića (1652 - 1952). Zagreb: JAZU.

Ritter Vitezović, Pavao. 1684. Oddilyenje sigetsko. Linz.

Ritter Vitezović, Pavao. 1685. Oddilyenja sigetskoga perva csetiri dila. Beč.

Ritter Vitezović, Pavao. 1695. Oddilyenje sigetsko. Zagreb.

Ritter Vitezović, Pavao. 1976. "Priričnik aliti razliko mudrosti cvitje". U Izabrana djela. Petar Zrinski, Fran Krsto Frankopan i Pavao Ritter Vitezović. Josip Vončina, ur. Zagreb: Zora, Matica hrvatska, 475-490.

Simpson, Catherine Anne. 1991. Pavao Ritter Vitezović. Defining National Identity in the Baroque Age. London: The School of Slavonic and East European Studies, The University of London (doktorska disertacija).

Solar, Milivoj 1996. Teorija književnosti. 17. izdanje. Zagreb: Školska knjiga.

Solar, Milivoj. 2011. Književni leksikon. 2. izdanje. Zagreb: Matica hrvatska.

Štěpán, Ludvík. 2015. "Poslovica”. U Grzegorz Gazda i Stowina Tynecka-Makowska. Rečnik književnih rodova i vrsta. Beograd: Službeni glasnik, 807-810.

Užarević, Josip. 2012. Književni minimalizam. Zagreb: Disput.

\section{PROVERBS IN VITEZOVIĆ'S ODILJENJE SIGETSKO}

Amongst numerous literary genres which Pavao Ritter Vitezović (1652 - 1713) included in his hybrid "epic poem" Odiljenje sigetsko [The siege of Siget] (1684) proverbs have a special place. Dispersed in all four parts of the text, proverbs are one of the most common genres in Odiljenje, as well as in Vitezović's heterogenous and extensive oeuvre. This article deals with the semantic diversity of proverbs in Odiljenje sigetsko, explores their possible origin (oral / written literature) and their function within the "poem", and compares them with proverbs from other selected Vitezović's works in Croatian. The analysis demonstrates that the omnipresence of proverbs in Odiljenje is essentially an echo of the clear baroque propensity for (oral) proverbs and proverbial forms, as well as evidence of Vitezović's strong desire to make his work available to less educated readers.

Keywords: Pavao Ritter Vitezović, Odiljenje sigetsko [The siege of Siget], proverbs, oral literature 